Portland State University

PDXScholar

12-23-1997

\title{
Spiritual Nourishment: A Central Christian Metaphor
}

Susan Sleeth Mosedale

Portland State University

Follow this and additional works at: https://pdxscholar.library.pdx.edu/open_access_etds

Part of the History of Religion Commons

Let us know how access to this document benefits you.

Recommended Citation

Mosedale, Susan Sleeth, "Spiritual Nourishment: A Central Christian Metaphor" (1997). Dissertations and Theses. Paper 5370.

https://doi.org/10.15760/etd.7243

This Thesis is brought to you for free and open access. It has been accepted for inclusion in Dissertations and Theses by an authorized administrator of PDXScholar. Please contact us if we can make this document more accessible: pdxscholar@pdx.edu. 


\section{THESIS APPROVAL}

The abstract and thesis of Susan Sleeth Mosedale for the Master of Arts in History were presented November 4, 1997 and accepted by the thesis committee and the department.

COMMITTEE APPROVALS:

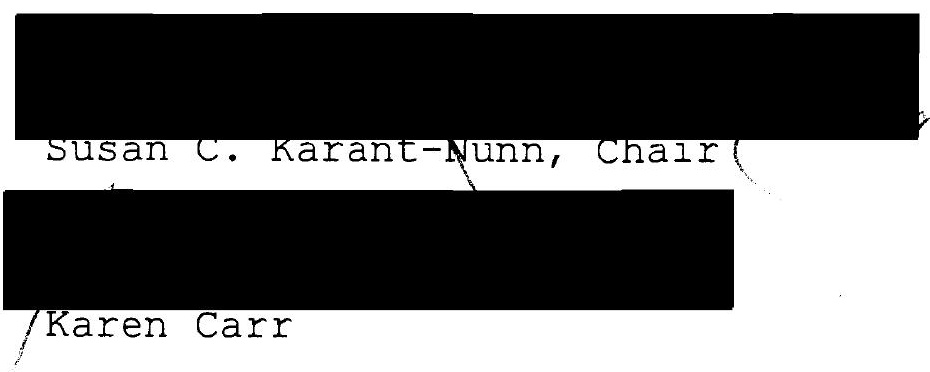

DEPARTMENT APPROVAL
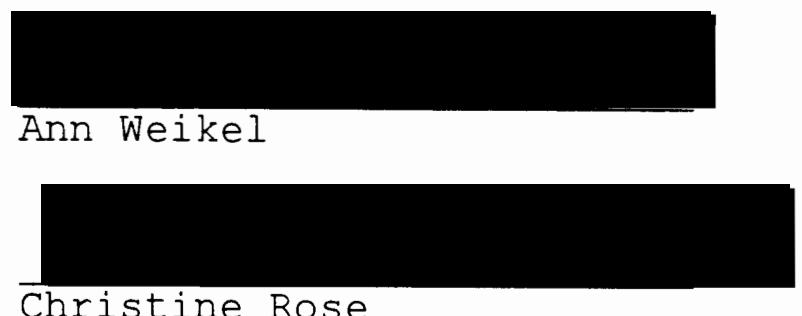

Representative of the office of Graduate Studies

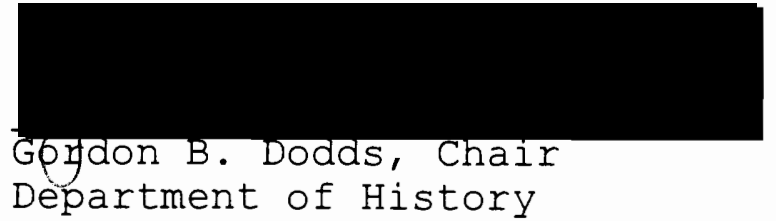

ACCEPTED FOR PORTLAND STATE UNIVERSITY BY THE LIBRARY

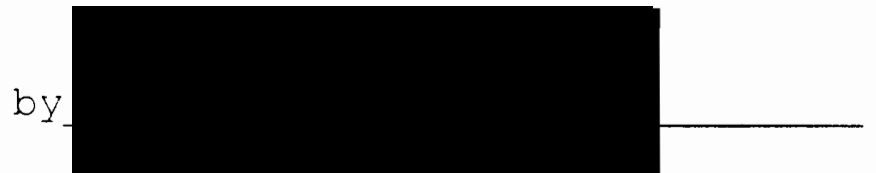

on

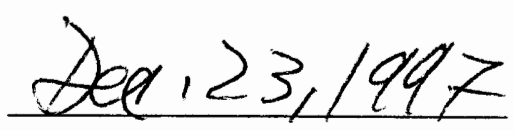




\section{ABSTRACT}

An abstract of the thesis of Susan Sleeth Mosedale for the Master of Arts in History presented November 4, 1997.

Title: Spiritual Nourishment: A Central Christian Metaphor

Since its origins, Christianity has been pervaded by a large array of images in which the spiritual realities are symbolized as food. Such images may be not only verbal, but visual or expressed in actions. These images can be seen as expressions of a spiritual nourishment metaphor; I apply here the meaning of "metaphor" proposed by the linguist George Lakoff and the philosopher Mark Johnson: a metaphor is a concept that structures ideas and actions as well as language. This thesis establishes the spiritual nourishment metaphor as a philosophical concept and begins to explore its history within Christianity.

The spiritual nourishment metaphor initially came to Christianity through the Hebrew tradition. I analyze the Jewish Letter of Aristeas, the early Christian Epistle of 
Barnabas, and selected writings of Augustine to study the development of an enacted expression of the metaphor, the spiritual practice of rumination. The function of rumination, to facilitate the understanding of the Scriptures, made it a force for group cohesion in early Christian communities. In Christian monasticism it became an important method for approaching union with God.

Augustine's textual uses of the spiritual nourishment metaphor show that its use would have been reinforced within Christianity by the existence in Latin of common word roots that convey both food-related and idea-related meanings. Ancient Hebrew and medieval Cistercian uses of the metaphor suggest that when a substance necessary for human survival (here, food) is in short supply, its symbolic use communicates that what is symbolized (here, the spiritual realities) is highly important to the culture.

The spiritual nourishment metaphor is a central element of Christian spirituality. The Eucharist is its supreme exemplar; the variety among exemplars of the metaphor suggests that it represents a convergence of expressions from varied origins. 
CONTENTS

PREFACE . . . . . . . . . . . . . . . . . . . . Chapter

1. INTRODUCTION . . . . . . . . . . . . . . 1

2. RUMINATION . . . . . . . . . . . 18

3. AUGUSTINE AND THE SPIRITUAL NOURISHMENT METAPHOR . . . . . . . . . 40

4. WHY MIGHT FOOD SYMBOLIZE THE SPIRITUAL? • 55

5. CONCLUSION . . . . . . . . . . . . . . 64 WORKS CONSULTED . . . . . . . . . . . . . . . . 72 
SPIRITUAL NOURISHMENT:

A CENTRAL CHRISTIAN METAPHOR

\author{
by
}

SUSAN SLEETH MOSEDALE

A thesis submitted in partial fulfillment of the requirements for the degree of

\author{
MASTER OF ARTS \\ in \\ HISTORY
}

Portland State University

1997 


\section{PREFACE}

Several years ago I was introduced to the twelfthcentury treatise Liber de panibus (Book of Breads) by Father Hugh Feiss, then librarian at the Mt. Angel Abbey Library. This text, composed around the year 1157 by the French abbot Peter of Celle, is a work in twenty-seven chapters, most of which take their title and allegorical theme from a type of bread, such as barley bread, bread of the little ones, and the multi-grain bread of Ezekiel. ${ }^{1}$ The whole is seen as alluding to the Eucharist. ${ }^{2}$

As I worked with the Liber de panibus, I saw that it could be studied as an exemplar of the metaphor of spiritual nourishment, which I was coming to understand as a major conceptual characteristic of medieval

1 The text exists in MS. Troyes 253 and MS. Paris BN lat. 2597. It is printed in Patrologiae cursus completus: series latina 202, ed. J.-P. Migne (Paris: 1855), 927-1046 (G. Martel, introduction to Petrus Cellensis, Commentaria in Ruth; Tractatus de tabernaculo, in Corpus Christianorum, continuatio mediaeualis 54 [Turnhout: Brepols, 1983], xii-xxvi).

2 Jean Leclercq, La spiritualité de Pierre de Celle, Librairie philosophique (Paris: J. Vrin, 1946), 32. 
spirituality. To place the spiritual nourishment metaphor itself in its medieval context, however, I needed to know its earlier history; yet I could find no historical discussions of the metaphor. Thus I began to investigate that history. The result is this thesis, which explores the early history of the spiritual nourishment metaphor within the Judaeo-Christian tradition and provides a foundation for a projected study of the metaphor in the twelfth century. Among the twelfth-century exemplars of the metaphor that I will study is the Liber de panibus of Peter of Celle.

I would like to acknowledge here the help and support that have made this thesis possible. I thank especially my advisor, Prof. Susan Karant-Nunn; Prof. Karen Carr; Prof. Donann Warren; Father Hugh Feiss; and many accommodating staff members of the libraries of Portland State University, Mt. Angel Abbey, the Beaverton Public Library, and the University of Portland.

I am grateful to the friends who have talked with me about my work and offered continuing encouragement. I appreciate the excellent practical advice of my son 
Dan. Most of all, I honor my husband Fred for his enthusiasm, perspective, and support at every level. 
CHAPTER 1

\section{INTRODUCTION}

And [God] commanded [the man], saying: of every tree of paradise thou shalt eat: But of the tree of knowledge of good and evil, thou shalt not eat. . .

- . And the serpent said to the woman: . . in what day soever you shall eat thereof, your eyes shall be opened: and you shall be as Gods, knowing good and evil.

Genesis $2: 16-3: 5$

When the Genesis narrative embodied God-like understanding in a fruit, it established food metaphor as a significant way of referring to knowledge in the Judaeo-Christian tradition. When later scriptural writers wrote about the kind of knowledge that humans may appropriately seek--not God-like knowledge, but knowledge about God--often they too used food metaphors. Food metaphor thus became a constant strand in attempts to name and discuss spiritual understanding in the JudaeoChristian tradition.

When food is used to symbolize what has been called "God's wisdom," "the ineffable," and "the spiritual 
realities," ${ }^{1}$ a spiritual nourishment metaphor is being applied. The Scriptures abound with examples of such a metaphor: ${ }^{2}$

O taste and see that the Lord is sweet. . . The rich have wanted, and have suffered hunger. (Psalm $33: 9,11$ )

You that have no money make haste, buy, and eat: come ye, buy wine and milk without money, and without any price. Why do you spend money for that which is not bread . . . Eat that which is good, and your soul shall be delighted in fatness. (Isaiah 55:1-2)

Son of man, eat all that thou shalt find: eat this book, and go speak to the children of Israel. And I opened my mouth, and he caused me to eat that book: And he said to me: Son of man, thy belly shall eat, and thy bowels shall be filled with this book. . . . And I did eat it: and it was sweet as honey in my mouth. (Ezekiel 3:1-3)

1 Gillian Feeley-Harnik, The Lord's Table: The Meaning of Food in Early Judaism and Christianity (Washington and London: Smithsonian Institution Press, 1994), 82 and passim; Karl Rahner, "Le début d'une doctrine des cinq sens spirituels chez origène," Revue d'ascetique et de mystique 13 (1932): 113; Jean Leclercq, Monks and Love in Twelfth-Century France: PsychoHistorical Essays (Oxford: Clarendon Press, 1979), 98 and passim. Similar phrases are found throughout spiritual writings.

2 I have quoted all scriptural passages in the Douai-Reims translation because that is the translation closest to a literal rendering of the Vulgate (Rembert Herbert, "The Way of Angels," Parabola 14, no. 2 [Summer 1989]: 82, 84). See Herbert for a consideration of how Biblical imagery in various translations diverges from the imagery in the vulgate. 
The angel of the Lord said to Habakkuk: Carry the dinner which thou hast into Babylon to Daniel, who is in the lions' den. (Daniel 14:33)

[Jesus] said to him: Blessed is he that shall eat bread in the kingdom of God. (Luke 14:15)

I am the bread of life. (John 6:48)

I am the living bread which came down from heaven. If any man eat of this bread, he shall live for ever; and the bread that I will give, is my flesh, for the life of the world. (John 6:51-52)

For my flesh is meat indeed: and my blood is drink indeed. (John 6:56)

. . those who . . have tasted also the heavenly gift, . . have moreover tasted the good word of God . . (Hebrews 6:4-5)

I gave you milk to drink, not meat; for you were not able as yet. (I Corinthians 3:2)

Early Christian and patristic writers, then medieval writers, used the spiritual nourishment metaphor freely:

Surely I am not unable to write you of heavenly things? No, but I fear inflicting harm on you who are infants. Bear with me, then, lest you be choked by what you cannot take in. (Ignatius of Antioch, Letter to the Trallians 5.1)

Barley was created in such a way that one can scarcely get to its kernel. . . Such is the letter of the old Testament . . . ; but if one gets to its kernel, it feeds and satisfies. (Augustine, Tractate on the Gospel of John 24.4.2)

I am accustomed to feed and be fed under your protection, in the Law and the prophets and the Psalms, in the meadows of the Gospels. (Bernard of Clairvaux, on the Song of Songs Sermon 33.7)

The flour that is most pure and white is called simila. But what is purer or whiter than the divine nature or wisdom? . . . Behold Paul, our priest, 
measuring for us a handful from the impossible-tocomprehend mass of the flour. (Peter of Celle, Book of Breads 10)

Yes, in three ways you [Lord] feed your own with yourself, as with three kinds of bread. The first bread, which we may call the God-man, is a loaf baked under ashes. . . . as if the loaf were God hidden and man manifest. . . (Serlo of Wilton, Commentary on the Pater Noster) ${ }^{3}$

Here is a twentieth-century expression of the metaphor:

[It is] as if the hunger for contemplation developed in inverse proportion to the hunger for eating. (Adalbert de Vogüe, To Love Fasting: The Monastic Experience $)^{4}$

Ignatius of Antioch, Letter to the Trallians, trans. William R. Schoedel, in Ignatius of Antioch: A Commentary on the Letters of Ignatius of Antioch, by William R. Schoedel, ed. Helmut Koester (Philadelphia: Fortress, 1985), 143; Augustine, Tractates on the Gospel of John Tractate 24, trans. John W. Rettig, Fathers of the Church: A New Translation, vol. 79 (Washington: Catholic University of America Press, 1988), 235; Bernard of Clairvaux, On the Song of Songs Sermon 33, in on the Song of Songs vol. 2, trans. Kilian Walsh, with an introduction by Jean Leclercq (Kalamazoo: Cistercian Publications, 1976; London and Oxford: Mowbray, 1976), 151; Petrus Cellensis (Peter of Celle), Liber de panibus (Book of Breads) 10, in Patrologiae cursus completus: series latina 202, ed. J.-P. Migne (Paris, 1855), 973, passage trans. Prof. Donann Warren; Serlo of Wilton, Commentary on the Pater Noster in MS. Trinity College 19, trans. Lawrence C. Braceland, in Braceland, "Thomas Becket and Monks' Bread," 111-12, in Benedictus: Studies in Honor of St Benedict of Nursia, ed. E. Rozanne Elder (Kalamazoo: Cistercian Publications, 1981), 108-14.

4 Adalbert de Vogüe, To Love Fasting: The Monastic Experience, trans. Jean Baptist Hasbrouck (Petersham, Mass.: Saint Bede's Publications, 1989), 60. 
The concept of a spiritual nourishment metaphor is easily demonstrable from these textual examples. It has not, however, been previously noted that the spiritual nourishment metaphor is not limited to texts: it is also expressed in actions and in visual images. A major enacted expression of the metaphor is rumination. Literally, rumination is the chewing of the cud by cows, sheep, goats, and related animals; metaphorically, rumination is an ancient human habit, involving mouth movements, that encompasses murmuring, learning, remembering, and meditating religious texts, usually the Scriptures. Rumination "works upon" religious texts to provide readers with spiritual nourishment. Here Augustine discusses rumination, in a passage that itself contains several examples of the spiritual nourishment metaphor:

You can eat the world's bread for an hour, and you have finished; the bread of the word you chew day and night. For when you hear, or when you read, you are eating; when you reflect on what you have eaten, you are ruminating. ${ }^{5}$

5 Augustine, Enarratio in Psalmum 36 sermo 3.5, in Corpus Christianorum: series latina 38: 371; trans. and quoted in Fidelis Ruppert, "Meditatio-Ruminatio: Une méthode traditionelle de méditation," Collectanea Cisterciensia 39 (1977): 85; my translation from the French. 
The quotation from st. Bernard on page 3 is from a passage that is also an allusion to rumination, although the term rumination is not mentioned.

A visual expression of the spiritual nourishment metaphor is found in the early thirteenth-century stained glass windows depicting bread at Chartres Cathedral. These windows depict two kinds of ritual bread that convey spiritual nourishment, the Eucharistic wafer and eulogia bread, a blessed bread that was distributed at the end of the Mass to those who did not receive communion. ${ }^{6}$ At the top of one window, Christ is depicted in heaven, holding a large eulogia loaf (Fig. 1a). In a scene lower in the window, a baker kneads dough in a gold altar-shaped trough; the visage of Christ (the work of a

6 The windows (whose donors are not documented) refer simultaneously to these liturgical breads and to the wheat that was the basis of the diocesan economy. The symbolism of the windows has been interpreted in Jane Welch Williams, Bread, Wine, and Money: The Windows of the Trades at Chartres Cathedral (Chicago and London: University of Chicago Press, 1993). See pp. 37-72 and especially plates 32, 80, and 81. Gradually after the twelfth century, eulogia bread was made available to all. The custom is discussed in Joseph A. Jungmann, The Mass of the Roman Rite: Its Origins and Development (Missarum Sollemnia), trans. Francis A. Brunner, vol. 2 (replica ed. Westminster, Md.: Christian Classics, 1986; reprinted 1992), 452-55; (original ed. n.p.: Benziger Brothers, 1951 and 1955). 
later glass artist) in seen on the dough in the trough (Fig. 1b).

As numerous usages of the spiritual nourishment metaphor suggest, the Eucharist is its quintessential exemplar in Christianity.

\section{Focus of the study}

Despite a wealth of verbal, enacted, and visual expressions of the concept of spiritual nourishment such as those above, I have found, to my surprise, no previous discussions of a spiritual nourishment metaphor qua metaphor--I have found, that is, no theoretical discussions of the concept of a spiritual nourishment metaphor even as expressed verbally, let alone in all three media. To my knowledge, such verbal, enacted, and visual expressions as those I have presented here have not been understood as exemplars of the single, pervasive spiritual nourishment metaphor that I believe they are.

Individual examples, which I call expressions, of the metaphor have of course been discussed--from other perspectives, apart from each other. For example, the metaphor of rumination has been the focus of several 


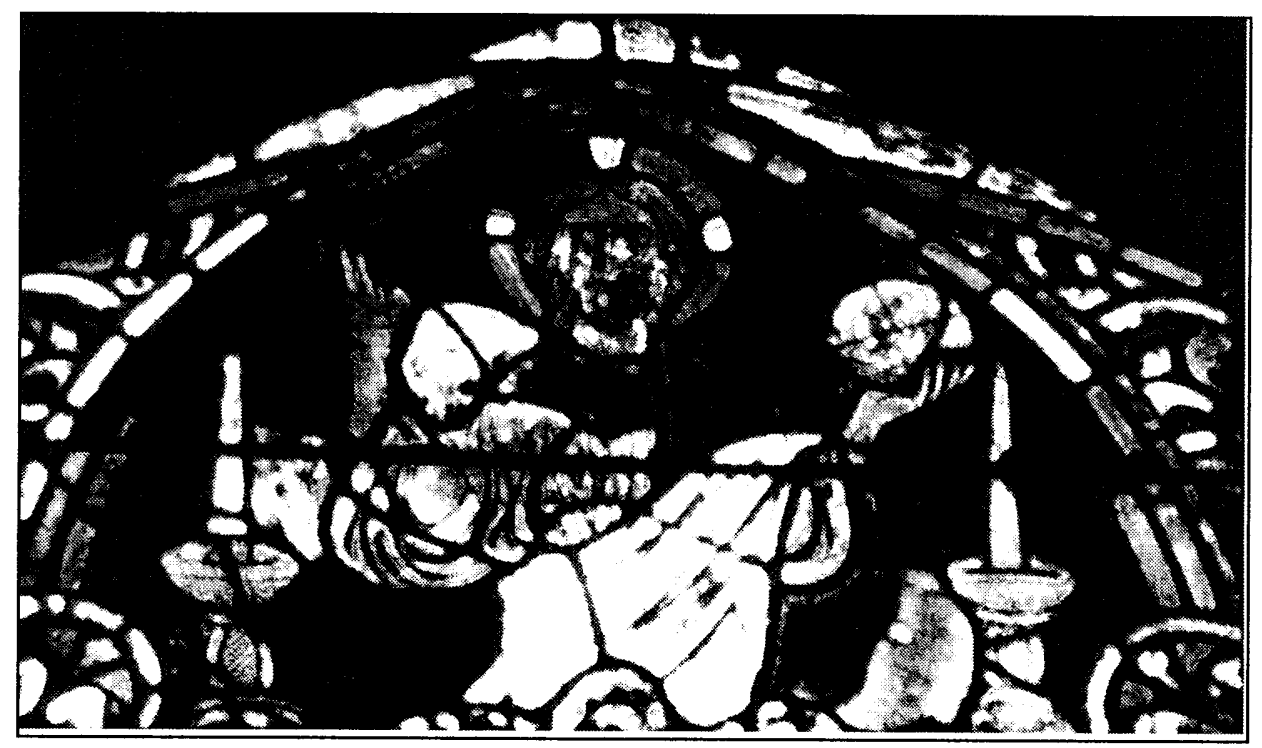

Fig. 1a. Christ holding Eulogia loaf.

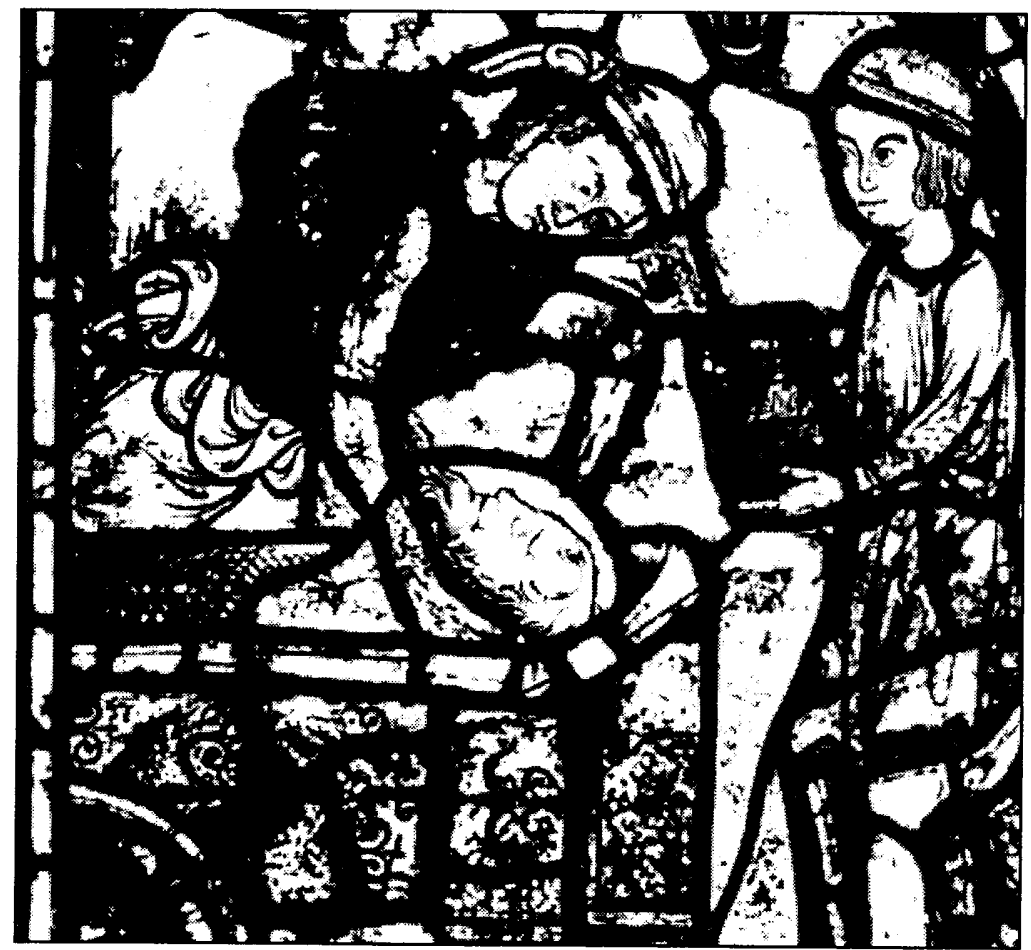

Fig. 1b. Baker kneading dough.

Fig. 1. Bread windows at Chartres Cathedral. From Williams, Bread, Wine, and Money, plates 81, 32. 
recent discussions, ' but it has not to my knowledge been linked to a wider spiritual nourishment metaphor. Nor have such phenomena as fasting, or reading in the monastery refectory, or the sculptured Romanesque capital at Vézelay known as the Mystic Mill, or the feeding aspect of the verbal metaphor known as Jesus as Mother, all of which I am investigating as exemplars of the metaphor. In this thesis I begin the work of integrating such phenomena within the concept of the metaphor.

My eventual aim is to investigate the spiritual nourishment metaphor in medieval Christianity. The thesis provides a foundation for such a study by exploring some of the early history of the metaphor. In the thesis I will focus initally on rumination: first I examine a Jewish text of the second century B.C.E., The Letter of Aristeas, that gives a theological rationale for linking human memory with animal digestion; next I consider the discussion of rumination in an early Christian text of the second century, the Epistle of

7 Two such discussions of rumination are found in Philip J. West, "Rumination in Bede's Account of Caedmon," Monastic Studies 12 (1976): 217-26; and Mary Carruthers, The Book of Memory: A Study of Memory in Medieval Culture (Cambridge: Cambridge University Press, 1990), Chap. 5. I consider their work below. 
Barnabas. I then proceed to Augustine, first to explore implications of his view of rumination, then to examine some of his textual uses of the spiritual nourishment metaphor. Finally, I consider why food might have been used to embody the spiritual in two cultures that used the spiritual nourishment metaphor, the early Hebrew and the twelfth-century Cistercian cultures.

To sum up: I have observed that Christianity is pervaded by a large number of images that liken the spiritual realities to material food; that these images may be verbal, enacted, or visual; and that the verbal and enacted expressions, at least, date from the old Testament period and continue to the present day. I propose that such images be understood as expressions of a spiritual nourishment metaphor, where metaphor signifies a concept that structures ideas, language, and actions.

\section{Relevant Literature}

Although I have not encountered any discussions of the spiritual nourishment metaphor as metaphor, the following works consider, to varying degrees, certain important uses of food metaphor in the Western tradition. 
Ernst Robert Curtius, in his classic European Literature and the Latin Middle Ages (1953), briefly discusses "alimentary metaphors" as a metaphoric type that, he implies, became a textual staple by or during the medieval period. ${ }^{8}$ That term, as Curtius mentions, includes food metaphors for entities other than the spiritual. Alimentary metaphors "are not unknown to Antiquity," he says, but he finds their chief source in the Bible. He gives a short sampling of New Testament and medieval examples; oddly, he gives only one of the wealth of Old Testament examples, and views even that through a purely Christian lens: "In the Christian story of salvation the tasting of the forbidden fruit and the institution of the Last supper are dramatic episodes." ${ }^{9}$ Michel Jeanneret, writing in 1987, could find no fuller exploration of alimentary metaphors in Western culture than Curtius's brief discussion. ${ }^{10}$

8 Ernst Robert Curtius, European Literature and the Latin Middle Ages, trans. Willard R. Trask, Bollingen Series no. 36 (New York: Pantheon, 1953), 134-36.

9 Ibid., 134.

10 Michel Jeanneret, A Feast of Words: Banquets and Table Talk in the Renaissance, transl. Jeremy Whiteley and Emma Hughes (Chicago: University of Chicago Press, 1991), 132, n. 30. Jeanneret's book is rich with 
Philip J. West and Mary Carruthers do accord significance qua metaphor to the rumination metaphor. Neither, however, remarks on any relation of rumination to a wider metaphor still, that of spiritual nourishment. West, writing in 1976, judged that rumination "must be considered one of the master allegories of the early Middle Ages," this because "it deals with the process by which the milk of true doctrine is produced"--that is, because rumination can be used in interpreting the Scriptures allegorically. ${ }^{11}$ West's aim is to examine the ruminative tradition as Bede understood it. Bede, in his Ecclesiastical History, used the term rumination to describe how Caedmon, the cowherd poet, had composed most of his heavenly songs: Caedmon had ruminated upon scriptural texts that he had heard explained and then expressed his understanding of them in his poems. ${ }^{12}$ West's emphasis is on the creative, compositional results of rumination as employed by Christian writers and preachers, and on the memorization of sacred texts that preceded such composition. He draws together an array of

implications and will be useful to me as I continue to develop my subject. 225.

11 West, "Rumination in Bede's Account of Caedmon," 22 Ibid., 224-25. 
texts that discuss or allude to rumination, including Clement, Cassian, Jerome, Fortunatianus, Augustine, Martianus Capella, Gregory, and a number of monastic customaries. Such a list allows us to glimpse how common a practice rumination must have been.

Carruthers, in her 1990 survey of medieval conceptions and processes of memory, gives what she calls "the digestion-rumination metaphor" an important place among medieval explanatory metaphors for memory:

Metaphors which use digestive activities are so powerful and tenacious that "digestion" should be considered another basic functional model for the complementary activities of reading and composition, collection and recollection

--that is, for the murmuring and ensuing memorization of texts, followed by meditation leading to composition. ${ }^{13}$ Carruthers finds the "digestion" metaphor important but less influential in Western culture as a model for memory than two other models, "the written surface" and "'the storage-room' and later 'strong-box. '"14

13 Carruthers, The Book of Memory, 165-66.

14 Ibid., chap. 1, especially pp. 16, 33. These latter two models Carruthers calls the two principal "'cognitive archetypes'" of ancient and medieval peoples for the concept of memory (16). She credits the philosopher Max Black for the concept of "cognitive archetype" (ibid.). 
Carruthers offers in her Chapter 5 a densely written discussion of rumination, drawing on such writers as Jerome, Martianus Capella, Augustine, and Hugh of st. Victor. She, like West, focuses on the mnemonic role of rumination and on composition as its result. By contrast, because my perspective is that of spiritual nourishment, I focus on the spiritual understanding attained via rumination, not the incorporation of that understanding into written and preached works.

The work of West and Carruthers helps to show the widespread occurrence of rumination in the monastic world. But surprisingly, given their historical perspective, neither of them discusses two sources seminal in the Christian tradition of rumination, the Letter of Aristeas and the Epistle of Barnabas. West incorrectly cites Philo Judaeus (d. Ca. 40 C.E.), rather than Aristeas, as the ultimate source of the rumination metaphor; West is aware of the Epistle of Barnabas, but alludes to it only in a phrase in a footnote. ${ }^{15}$ My aim being to trace the history of the spiritual nourishment

15 West, "Rumination in Bede's Account of Caedmon," 218, 219. For Philo, see my p. $26, \mathrm{n} .15$. 
metaphor, I will explore the discussions of rumination in both the Aristeas and Barnabas texts.

I turn now to the important work of the anthropologist Gillian Feeley-Harnik, who has explored the use of food as language within early Judaism and early Christianity. ${ }^{16}$ Although Feeley-Harnik does not discuss the concept of spiritual nourishment, much that she discusses may be turned to that theme. She finds that for the Jewish sects, food law came to symbolize God's entire law, so that adhering to the food laws implied that one kept the whole of God's law. A related principle, implied in her work but not articulated, must be that offering, partaking of, and refraining from particular foods in accordance with Jewish law would have nourished one spiritually: God's law would have been supremely spiritually nourishing. I shall return to Feeley-Harnik's work later.

16 Gillian Feeley-Harnik, The Lord's Table: The Meaning of Food in Early Judaism and Christianity (Washington and London: Smithsonian Institution Press, 1994). Reprint, with additions, of The Lord's Table: Eucharist and Passover in Early Christianity, 1981 (publisher not given). 


\section{Theory and Terms}

My characterization of a spiritual nourishment metaphor draws on, and helps provide support for, philosophic ideas about metaphor developed by the linguist George Lakoff and the philosopher Mark Johnson in their book Metaphors we Live By. ${ }^{17}$ Their title shows their perspective: metaphors influence our perceptions and our actions, often strongly. Lakoff and Johnson see a metaphor as a concept, a governing idea (my term), that is manifested in numerous individual expressions. Drawing on hundreds of examples of verbal expressions, examples of what people say, they tease out the metaphorical concepts, i.e., metaphors, implied in common speech, then analyze how those metaphors "structure" our ideas about our world, and thence our speech and our actions.

Lakoff and Johnson do not identify a spiritual nourishment metaphor; among influential metaphors they do identify and analyze, however, is one they call Ideas are Food. ${ }^{18}$ The metaphor Ideas are Food applies food-related

17 George Lakoff and Mark Johnson, Metaphors We Live By (Chicago: University of Chicago Press, 1980).

18 Ibid., chaps. 10, 22. The authors list a number of governing metaphors that influence how we communicate 
concepts to such entities as ideas and books; examples are locutions like "food for thought," "voracious reader," "digested the information," "devoured the book," and "browsing room."19 I see the spiritual nourishment metaphor as a "subset" of the metaphor Ideas are Food: the spiritual nourishment metaphor applies food-related concepts to spiritual ideas and entities.

Lakoff and Johnson espouse metaphor as "one of our most important tools for trying to comprehend partially what cannot be comprehended totally: our feelings, aesthetic experiences, moral practices, and spiritual awareness."20 St. Augustine would agree, as I will show.

about ideas, including Ideas are Light-Sources (p. 46), which metaphor, like Ideas are Food, is obviously manifested both within and outside of Christianity.

19 Ibid., 46-47. (The last example is mine.) Lakoff and Johnson almost never mention languages other than English. It is evident, however, that relevant English applications of the metaphor Ideas are Food often echo Latin applications, as when ruminate (and Latin rumino) and devour (and Latin devoro) are applied to ideas.

${ }^{20}$ Ibid. , 193. 


\section{CHAPTER 2}

\section{RUMINATION}

Rumination is the spiritual practice, drawing upon texts, by which monastic readers and hearers lived the metaphor of ingesting and assimilating spiritual wisdom. I focus initially on rumination because of its antiquity and its key role in monastic life in early and medieval Christianity.

The aim of monastic life was union with God. The monk and scholar Jean Leclercq, writing of twelfthcentury monasticism, said that

the great difference between the theology of the schools and that of the monasteries resides in the importance which the latter accord the experience of union with God. This experience in the cloister is both the principle and the aim of the quest. ${ }^{1}$

1 Jean Leclercq, The Love of Learning and the Desire for God: A Study of Monastic Culture, trans. Catharine Misrahi, 3d ed. (New York: Fordham University Press, 1982), 212. See also Leclercq, "Monasticism and Asceticism: II. Western Christianity," trans. Dennis Tamburello, in Christian Spirituality: Origins to the Twelfth Century, ed. Bernard McGinn and John Meyendorff, with Jean Leclercq (New York: Crossroad, 1985), 124. Secular scholars who have tried to comprehend the mental 
An important component of the monk's path toward such union was the rumination of religious texts, chiefly the Scriptures. Commentaries or sermons could also be ruminated, however: Augustine, Caesarius of Arles (d. 542 ) and Bernard of Clairvaux urged their monastic audiences to ruminate the preaching they heard. Rumination was carried out, on texts acquired by reading or hearing, not only during times designated for reading and prayer but also during physical labor. Rumination was not inherently a group activity, but it could be carried out in common: Jerome's Latin translation of the Rule of Pachomius instructs brothers to ruminate together the doctrinal instruction delivered during catechesis. ${ }^{2}$ Thus rumination was employed in varying ways and circumstances; in all its variations, its role in

and spiritual world of monasticism have often drawn on the writings of Leclercq, particularly his Love of Learning and the Desire for God, composed to expound to novices the tradition they were about to embrace (viiviii).

2 Fidelis Ruppert, "Meditatio-Ruminatio," 81, 86-87. Ruppert cites Augustine, Enarratio in PS. CIII Sermo IV, 19; Caesarius of Arles, Sermo LXIX, 5; Bernard of Clairvaux Serm. Divers. 16, 7; and Jerome, Rule of Pachomius Praecepta 122. 
enabling the monastic goal made it a significant expression of the spiritual nourishment metaphor.

The word ruminatio was often used for meditatio. The scholar-monk Fidelis Ruppert, who surveys rumination's pervasion of Christian monastic life and texts, leaves the impression that, although the term meditatio was the more often used, the term ruminatio was often used and universally understood. The two aspects of rumination central to monasticism are distinguished by Ruppert as follows: one aspect is "to repeat a saying or a text and indeed to repeat it frequently if not continuously"--the effect of which is, obviously, to memorize it. The other aspect is "to savor and to assimilate these words inwardly, to make the repetition fruitful." And, he adds, "this [latter] aspect of rumination is largely identical to monastic meditation" in early Christian and central medieval times. (Vis-àvis the word "largely," Ruppert does not specify any areas of difference during the given time period. Leclercq indicates the identity of the two practices. ${ }^{3}$ )

3 Ruppert, "Meditatio-Ruminatio," 91. Leclercq, Love of Learning, 73. I have translated into English all quotations from Ruppert and other sources in French. 
"By very reason of its calling attention to the divine mysteries and giving the spirit the freedom to consider them," writes Leclercq, meditation/rumination was "a delightful spiritual activity."4 This observation suggests the aspect of rumination that Ruppert accentuates, its non-rational character; the word meditation, by contrast, eventually came to be used for a more intellectualized process:

The concept of meditation has undergone a transformation such that, little by little, we have come to understand by it a reflection on the truths of the faith. In modern times, the rational element has largely predominated [in] contemplation and meditation. . . However, the concept of rumination, better than that of meditation, is strong enough to withstand this danger of intellectualism. The image of mastication, of digestion and interior assimilation is better suited to express the desired result, which is to cause the Word of God to pass not into the head but into the heart [my emphasis]. ${ }^{5}$

4 Leclercq, "Monasticism and Asceticism," 419.

5 Ruppert, "Meditatio-Ruminatio," 91. Note how this modern commentary associates the metaphor of rumination with emotion by using the metaphor of the heart. Also, in asserting the suitability of the rumination image to a non-rational process, could Ruppert be referring to rumination's link with animals? Did he also mean that the "picture-inducing" effect of the rumination metaphor helps to sustain the non-rational character of the concept? 
In his commentary on the Rule of Saint Benedict, Adalbert de Voguié shows how intrinsic to the monastic day was this activity of seeking out spiritual nourishment:

The texts read and learned during the hours of lectio [monastic reading] are then "meditated," that is, repeated by mouth and heart during the work hours. Thus the entire day rings with the divine word. . .

. . The text read is Holy Scripture, the nourishment of the soul. The time of reading should fill the soul, like a meal, with "enough for the whole day." ${ }^{6}$

Note that although de Voguié uses meditation, not rumination, for the practice, he uses the spiritual nourishment metaphor for the text that meditation will "process." The Scriptures were said to be or to provide spiritual nourishment, whatever the word used for the practice of obtaining that nourishment. Note too that religious texts need not themselves incorporate the spiritual nourishment metaphor in order to be considered sources of spiritual nourishment.

\section{Early Meditation in the Hebrew Culture}

Rumination had an early metaphorical sense outside of Judaeo-Christian culture. The word was used in

'Adalbert de Voguié, The Rule of Saint Benedict: A Doctrinal and Spiritual Commentary, trans. John Baptist Hasbrouck (Kalamazoo: Cistercian Publications, 1983), 242-43. 
classical antiquity for certain "intense mental assimilation"; ${ }^{7}$ as Carruthers notes, the Oxford Latin Dictionary finds rumino used in the sense of "turn over in the mind, meditate" as early as the third century B.C.E. ${ }^{8}$ And murmured meditation was a classical practice. ${ }^{3}$

To understand the meaning of rumination in the Judaeo-Christian tradition, we must begin with the earliest uses in the old Testament of the Hebrew haga (meditate), drawing upon the information given by Emmanuel von Severus and Aimé Solignac. ${ }^{10}$ The primitive sense of haga was "to murmur at half-voice"; but it was used as well for animal calls, as for the sound of the Rabbow.

Ruppert, "Meditatio-Ruminatio," 82-83, following

${ }^{8}$ The earliest use given in the oxford Latin Dictionary occurs in a fragment by the earliest Roman dramatist and epic poet, L. Livius Andronicus (ca. 284204 B.C.E.).

9 West, "Rumination in Bede's Account of Caedmon", 222; Carruthers, The Book of Memory, 86, 164.

10 Emmanuel von Severus and Aimé Solignac, "Méditation" I, in Dictionnaire de spiritualité ascétique et mystique doctrine et histoire, t. 10 (Paris: Beauchesne, 1980), 906-914. This article is a valuable review of many earlier discussions of meditation. I have compared scriptural passages cited with the Vulgate versions; I give here the Douai-Reims translations. 
dove in Isaiah 38:14: "I will cry like a young swallow, I will meditate like a dove." When applied to humans, haga typically had a mental or spiritual component; this sense seems inherent in its first use in the old Testament, in Joshua 1:8: "Let not the book of this law depart from thy mouth [my emphasis]: but thou shalt meditate on it day and night, that thou mayst observe and do all things that are written in it: then shalt thou direct thy way, and understand it."

The oral repetition implied in that passage implies that God's law will be committed to memory during meditation; in other scriptural texts, like Psalm 76:1213, meditate explicitly takes on associations of remembering: ${ }^{11}$ "I remembered the works of the Lord: for I will be mindful of thy wonders from the beginning. And I will meditate on all thy works."12 The oral character of meditation is reiterated: "the seat or the organ of

11 Ibid., col. 907.

12 Psalm 76:12-13. Similarly in Psalm 142:5: "I remembered the days of old, I meditated on all thy works: I meditated upon the works of thy hands" (von severus and Solignac, "Méditation," col. 907). 
meditation is above all the throat, the larynx"--that is, the vocal apparatus. ${ }^{13}$

The Greek and Latin renderings of haga, say the authors, broadened the original sense, "murmur," of the Hebrew word: the range of meaning of the Greek rendering, $\mu \varepsilon \lambda \varepsilon \tau \tilde{\alpha} v$, includes "give attention to," "be mindful of," and "watch for." The Latin rendering, meditari, includes among its senses "practice, train," and "accustom oneself, become familiar," with a wide range of applications, from the handling of weapons to memorizing. ${ }^{14}$

Three characteristics of meditation will be important for this discussion: its association with both animals and humans, its involvement of the vocal apparatus and of sound, and its association with memory.

\section{The Letter of Aristeas}

Keeping in mind those three aspects of meditation, let us examine now an early discussion of metaphorical rumination. It occurs in a Greek text of ca. 130 B.C.E. known as the Letter of Aristeas, and it links visible

13 von Severus and Solignac, "Méditation," col. 907. 14 Ibid., cols. 907-908. 
animal rumination with human remembering and meditation on God's works. The Aristeas text was not actually a letter, but an "imaginative work" on ethical themes, built on a discussion of the Greek translation of the Hebrew Pentateuch. Its author was a Hellenized Jew of Alexandria, apparently writing for a tolerant audience like himself. ${ }^{15}$

In the text of the treatise, the high priest Eleazar gives an allegorical explanation for the old Testament designation of certain animals, food, and drink as clean or unclean. A chief reason for those designations, the author asserts, is to foster the contemplation of God. ${ }^{16}$ Among the animals clean for eating are ruminants with cloven hooves, as is set down in Levit. 11:3. "By such examples [as these permissible animals]," Aristeas writes, "the lawgiver [Moses] has commended to men of

15 Moses Hadas, introduction to Aristeas to Philocrates (Letter of Aristeas), ed. and trans. Moses Hadas (New York: Harper and Brothers, for the Dropsie College for Hebrew and Cognate Learning, 1951), 6, 54-65. Aristeas's allegorical interpretation of rumination was also offered by Philo of Alexandria (d. ca. 40 C.E.) in Special Laws IV (Hadas 161, n. 154). For the dating of the Aristeas text, see Hadas 9-54 and 152; see esp. 15-17 for the priority of Aristeas over Philo. Hadas's dating is supported by Feeley-Harnik (27) and her source.

16 Aristeas to Philocrates, 159. 
understanding a symbol" of how they should live--that is, the Hebrews should emulate the virtues symbolized by the animals that they may eat. ${ }^{17}$ Now one of the virtues symbolized by cloven hooves is "that we are set apart" (divided, as is the hoof) from other, unjust, men; ${ }^{18}$ and

the lawgiver has characterized men who possess the aforementioned trait of separation as possessing the trait of memory also. For "whatsoever [animal] parteth the hoof and cheweth the cud" to thinking men clearly signifies memory. For the [visible] chewing of the cud is nothing else than recalling life and its subsistence, since life appears to subsist through taking food. And therefore does [Moses] admonish us through scripture, when he says "Thou shalt well remember what great and marvelous things the Lord thy God did in thee; when clearly understood . . . [such "things"] do indeed appear "great and glorious" [my emphases]. ${ }^{19}$

In other words, when the Hebrew sees the ruminant animal chewing its cud, he is to remember the life that that chewing (of "subsistence") sustains--and he should remember then his own life, his own body ("in thee") 20 and what sustains it, God. And here Aristeas extols as a

17 Ibid. As I will discuss later, the anthropologist Gillian Feeley-Harnik has characterized food as a "language" of the Jewish sects. Here, Aristeas explicitly makes that very point.

18 Aristeas to Philocrates, p. 161

19 Ibid., 161. Hadas says this quotation melds Deut. $7: 18$ and 10:21 (n. 155).

20 Hadas, Aristeas to Philocrates, confirms my understanding of this phrase (161 n. 155). 
marvel of God the human body, from its physical

functions, among which he emphasizes digestion, to its

even more remarkable intellectual capacities:

In the first place there is the articulation of the body and the means for digesting food, and the distribution of the members; but much more does the orderly arrangement of the senses, the working and invisible movement of the intellect, its acuteness in conforming action to any situation and its discovery of arts, indicate infinite scope.

Therefore he [Moses] exhorts us to bear in mind that the capacities mentioned are preserved in their ordering by divine power.

These marvels of human functioning are sustained by God and his power, and we ought "continually" to "call. . . to mind" God and his power; God is the ultimate object of this meditation. ${ }^{21}$

This act of memory and meditation is both inspired and signified by the digestive rumination of certain animals that the devout may eat ("'whatsoever . . . cheweth the cud' . . clearly signifies memory"; again, "the chewing of the cud is nothing else than recalling life and its subsistence"). We saw earlier that haga has already been associated with human memory and with the vocal apparatus of both humans and animals; now Aristeas has enlarged the pool of association by adding

21 Ibid., 161-63. 
specifically the ruminant animal, which visibly moves its mouth, as did meditating humans, while it "re-uses" its food, which inspires humans' re-turning to thoughts of God.

Indeed, one might say that eating the meat of the ruminant "induces in" the eater an analogue of the animals' ruminating trait--not in a magical transference, but because one should eat that meat mindfully. For, Aristeas writes, "by detailed injunctions concerning food and drink and touch he bids us to do nothing . . heedlessly" (my emphasis). Thus it is not alone in the act of eating the approved meat, but also in the manner of eating it, that eating the approved food would remind one of his own marvelous faculties and God their source. Note further that those faculties include the faculty of memory, which would thus recall itself as a marvel that enables one to attain to God its maker. Thus Aristeas's explication implies an intimate linking of the memory faculty with what is remembered. Such a memory faculty would be doubly spiritually nourishing, providing both mechanism (human rumination) and substrate (the human memory faculty itself) for spiritual nourishment. 
A postscript: the early highlighting of human digestion in Aristeas's list of bodily marvels could be an intentional reminder that digestion is the human feature that enables one to comply literally with the food laws. For the mindful literal observance of those laws is, after all, the basis for understanding them allegorically.

\section{The Epistle of Barnabas}

A text in Greek known as the Epistle of Barnabas, dated to the second quarter of the second century C.E., is one of the earliest Christian texts to discuss rumination. ${ }^{22}$ Analysis of it reveals clues to the importance of rumination in early Christianity. Some level of acceptance of the author's ideas is indicated by the fact that the Epistle was translated into Latin, and

22 For dating of the Epistle of Barnabas, see Pierre Prigent, introduction to Épitre de Barnabé, Sources Chrétiennes no. 172, transl. and with an introduction by Pierre Prigent, Greek text established by Robert A. Kraft (Paris: Éditions du Cerf, 1971), 26-27. Ruppert says that Barnabas is "without doubt one of the oldest" Christian texts to discuss rumination ("MeditatioRuminatio," 82). 
presumably thus circulated, in the second or third century. ${ }^{23}$

The Barnabas text (like Aristeas, a treatise rather than a letter) is a compilation of teachings, from varied sources, that includes allegorical interpretations of the old Testament. Its discussion of rumination is one of those allegorical interpretations. The author (no longer believed to have been the Barnabas associated with Paul) was apparently a gentile Christian writing for one or several gentile Christian communities. ${ }^{24}$

Like Aristeas, the Barnabas author grounds his discussion in the Jewish dietary laws. For Aristeas, applying the dietary laws symbolically had arisen from following them literally. But Barnabas is not concerned that the faithful actually eat according to those laws. Indeed, says the Barnabas text, "not to eat [the proscribed animals] is not a commandment from God; rather, Moses was using a [wholly] spiritual language."25 25.

23 On the translation, see Prigent, introduction,

24 Prigent, introduction, 9-15, 27-30. Prigent cites Acts 11:25-15:39 and I Cor. 9:6 as scriptural texts once thought to have referred to the author of the Epistle.

25 Épître de Barnabé, 149. 
The Epistle of Barnabas begins its discussion of rumination as follows:

Moses said: "You may eat of everything that both ruminates and has a cloven hoof." What does he mean? [He means] that such [an animal], when it takes in [or, "mentally grasps" ${ }^{26}$ ] its food, recognizes him who feeds it and, when it is resting, visibly finds its delight in its food. The formulation of the commandment is particularly felicitous. .

The writer does not tell us why he finds the formulation felicitous. But he has already demonstrated that the very word ruminate calls up felicitous associations, for he has expanded Moses's simple instruction into a wordpicture that suggests a pleased ruminating sheep ("visibly [i.e., chewing] finds its delight in its food") fed by its shepherd (it "recognizes him who feeds it"). Surely an early Christian would have inferred from this Christ the Good Shepherd, for the verbal imagery is consonant with early visual representations of Christ, paintings or carvings of a beardless youth carrying a sheep on his shoulders or standing among sheep. ${ }^{28}$

26 I thank Prof. Karen Carr for confirming that the Greek verb lambano carries implications of both the physical and the mental senses of ruminate.

27 Épître de Barnabé, 157-59.

28 Beckwith reproduces such an image of the Good Shepherd in the Catacomb of Priscilla dating from the 
What is it that Barnabas pictures the sheep being fed? It is words, scriptural words, for the writer continues:

What does [the commandment] mean? [It means] attach yourself to those who fear the Lord, who meditate in their heart the exact meaning of the word that they have received, those who teach and keep the commandments of the Lord, who know that meditation is a joyful exercise and who ruminate the word of the Lord [my emphases]. ${ }^{29}$

This text offers valuable clues about the role of rumination in early Christian practice. One aspect of its role can be teased out as follows:

Meditation is mentioned twice in the passage, once as a method for coming to the true sense of the Scriptures ("meditate in their heart the exact meaning of the word they have received") and again as a practice that brings spiritual "joy"; and note that the heart is again named as the locus of rumination, the means to this joy. ${ }^{30}$ Note too that rumination is equated in the text with meditation, as can be inferred from the two usages

later second or the third century (John Beckwith, Early Christian and Byzantine Art, 2d [integrated] ed. [Harmondsworth: Penguin, 1979], 21). (I have not seen such an image reproduced in which Christ is actually feeding the sheep.)

29 Épître de Barnabé, 159.

30 Recall Ruppert's association of rumination with the heart rather than the head (see my p. 21). 
"meditate . . the exact meaning of the word" and "ruminate the word of the Lord."

Note now that meditation/rumination is given place in a short series of spiritual acts that are centrally important to Christianity: keeping the commandments, fearing the Lord, and teaching the commandments. Further, rumination is said to be practiced by "those who teach . . the commandments" --that is, by the spiritual and moral leaders of the community. All of these associations indicate the importance of rumination. And that importance must stem from the function of rumination within early Christianity, which, as the passage itself indicates, is to facilitate understanding of the Scriptures ("meditate in their heart the exact meaning of the word that they have received"; "ruminate the word of the Lord"). For interestingly, although Aristeas had propounded God's works in the human body as foci for rumination that would lead to the contemplation of God, the Barnabas writer applies rumination to texts only, "the word of the Lord." Thus in the Barnabas conception, rumination uses as its "substrate" what it would use in medieval monasticism. 


\section{The Social Importance of Rumination}

Because of its function as a route to understanding the Scriptures, I find it likely that rumination strengthened social cohesion within early Christian communities. For in focusing on the scriptures, it focused on the texts that enunciated the raison d'être for Christianity and thus for the Christian communities themselves. Rumination would therefore have reinforced the sense of purpose and the sense of community among Christians.

The Barnabas author himself seems to promote rumination as a force for community cohesion. This is suggested by the form in which he gives his interpretation of Moses's instruction. For he situates his directive to emulate ruminating animals at one remove from the animals themselves: rather than writing, "Ruminate symbolically as these animals do literally," he writes: "Attach yourself to those who . . ruminate the word of the Lord." I interpret the writer's indirection here as follows:

The text implies that the Christian is likely to acquire the habit of rumination in the company of the devout. In such company, we can see, the spiritual 
practices of the individual would be supported by the presence of others who valued and practiced the same habits. The individual's advancement in the faith would be facilitated by community support; in turn, her or his spiritual maturing would reinforce the strength of the community .

This inference about the Barnabas author's spiritual-cum-social motive in urging rumination is consonant with the judgment of John D. Zizioulas on the social nature of early Christian spirituality: "The church was a set of relationships, which provided one with a new identity," he writes; and further on: "[Early Christian] spirituality is an ecclesial and not an individual experience." ${ }^{31}$

If we consider the minority status of Christianity in the early second century, we can see that promoting rumination in a way that would promote community cohesion as well would have benefited the early church. The circulation of the Epistle of Barnabas in its Latin

31 John D. Zizioulas, "The Early Christian Community," in Christian Spirituality: Origins to the Twelfth Century, ed. Bernard McGinn and John Meyendorff, with Jean Leclercq (New York: Crossroad, 1985), 28, 30. 
translation, then, would have fostered both rumination and social cohesion among Christians. ${ }^{32}$

\section{Feeley-Harnik's Work and the Spiritual \\ Nourishment Metaphor}

When Aristeas Iinked the Mosaic dietary rules to the behavioral traits of the potential food animals, he said of the approved, non-predatory, birds: "By such examples, then, the lawgiver has commended to men of understanding a symbol that they must be just and achieve nothing by violence. . . " "33 This assertion, that God has used food to communicate behavioral ideals to humans, is an explicit early statement that confirms twentieth century identifications of food as an important language within the Hebrew culture.

In The Lord's Table, the anthropologist Gillian Feeley-Harnik surprisingly does not discuss either rumination or the spiritual nourishment metaphor, nor does she refer to any philosophical studies of metaphor. ${ }^{34}$ But, analyzing food use in the Hebrew

32 On the circulation of the letter, see my p. 31.

33 See Aristeas to Philocrates, 159.

34 Feeley-Harnik refers to the Letter of Aristeas, but to sections unrelated to rumination (The Lord's 
culture, she comes to conclusions consonant with those of Lakoff and Johnson about the metaphor they call Ideas are Food. Thus her work provides a context for the spiritual nourishment metaphor, which I see as a special case of the metaphor Ideas are Food. Feeley-Harnik writes in The Lord's Table as follows:

Food, articulated in terms of who eats what with whom under which circumstances, [was] one of the most important languages in which Jews conceived and conducted social relations among human beings and between human beings and God. Food was a way of talking about the law and lawlessness that dated at least to the Babylonian Exile in the mid-sixth century B.C.E., when the Pentateuch and Deuteronomic books are established to have taken nearly final form.

Now food as a language of "social relations between human beings and God" is consonant with the idea of a spiritual nourishment metaphor. In Feeley-Harnik's perception,

food was identified with God's word as the foundation of the covenant relationship in scripture and in sectarianism. During the inter-Testamental period, as God's word became increasingly identified with the law, food law came to represent the whole law. Sectarianism was expressed above all through different interpretations of the dietary rules.

The author finds that Christians "inverted," as she says, the meaning of the Hebrew language of food:

Christians of the first century C.E., as observant Jews, used the language of food to establish both the legitimacy of Jesus and the

Table, 26-27, 99, 136). Nor does she allude to the above statement by Aristeas.) 
novelty of his interpretation of the law, which required different kinds of relations among human beings and God from those advocated by other sectarians. The last supper. . . transformed the meaning of the [passover] meal and the sacrifice on which it was based. Jesus' passover. . . was a rejection of familial and national separatism. His new covenant included all humanity. ${ }^{35}$

Feeley-Harnik shows in the Scriptures a strong reliance on food imagery for what she often calls "God's wisdom," ${ }^{36}$ as in Proverbs $9: 1-6$; in that text, personified Wisdom prepares a banquet, then proffers the invitation: "Come, eat of my bread and drink of the wine I have mixed. Leave simpleness, and live, and walk in the way of insight." ${ }^{37}$ Feeley-Harnik's analysis documents that the use of food to symbolize God and his attributes was integral to the spiritual and cultural tradition that produced Christianity.

35 Feeley-Harnik, The Lord's Table, 72, 165, 166.

36 Ibid., 166 .

37 Ibid., 83. This passage is as quoted by FeeleyHarnik from the translation in the New Oxford Annotated Bible with the Apocrypha, 1977. 


\section{CHAPTER 3}

\section{AUGUSTINE AND THE SPIRITUAL NOURISHMENT METAPHOR}

Augustine's use of the spiritual nourishment metaphor must be probed because of his great influence in the medieval west. He richly employed the spiritual nourishment metaphor in his writings, and certain of his discussions and uses of the metaphor reveal important themes that can be traced through the Christian history of the metaphor. These include the stomach of memory, the Eucharist as the ultimate spiritual nourishment, and a characteristic of the Latin language itself that, as I will show, must have predisposed its users to the spiritual nourishment mind-set.

Yet Augustine applies the spiritual nourishment with caution as well as flair, sometimes both simultaneously. In some of his works he seems intent on emphasizing the metaphorical character--that is, apparently, the limitations--of the concept of spiritual nourishment. Such cautions can be detected both in his writings on 
rumination and in his textual uses of the spiritual nourishment metaphor.

West gives a valuable partial list of citations of Augustine's discussions of rumination; West himself discusses those writings only cursorily, however. ${ }^{1}$ Carruthers analyses the constituents of rumination in two instances of it described by Augustine (in neither case, interestingly, does he use the word rumination). ${ }^{2}$ My own purpose is to explore what I see as Augustine's ambivalence toward both the rumination metaphor and the wider spiritual nourishment metaphor.

Augustine was influenced by the idea found in the Aristeas and Barnabas letters, and elaborated by other Jewish and Christian writers before Augustine, that the devout are inspired to spiritual rumination by the digestive rumination of the "clean" animals. ${ }^{3}$ As a 221.

1 West, "Rumination in Bede's Account of Caedmon,"

2 Carruthers, The Book of Memory, 170-73.

3 This influence is shown in Augustine's discussion of rumination in his sermon 149 (examined below). Other early writers who elaborated on the theme include Philo, Clement (d. ca. 215), and Origen (d. Ca. 254) (Prigent, Épitre de Barnabé, 158, n. 2; see Prigent for citations to the works of these and other writers). Clement, in Stromata 5, mentioned the Barnabas writer as a source (Ruppert, "Meditatio-Ruminatio," 83). 
rhetorician Augustine would also have known the classical ruminatio. From this mixed background, Augustine tries to understand how the ruminant animal's stomach and its functioning might serve as a model for memory. ${ }^{4}$ Thus, in the Confessions, Augustine probes the limits of the metaphor of the memory stomach:

No doubt, then, memory is, as it were, the stomach of the mind, whereas gladness and sadness are like sweet and bitter food. When they are entrusted to the memory, they are as if transferred to the [ruminant animal's] stomach and can there be stored; but they cannot be tasted [i.e., re-experienced]. It is ridiculous to think this illustration offers a real parallel; nevertheless, it is not wholly inapposite [my emphases]. ${ }^{5}$

4 The stomach was not the only metaphor by which Augustine tried to understand memory; in Book 10 of the Confessions he compared the memory to numerous locales that approximated the storage room of Carruthers's classification.

5 Augustine, Confessions 10.14.22, trans. and with an introduction and notes by Henry Chadwick (Oxford and New York: Oxford University Press, 1991), 191. It is difficult to make sense of this passage without inserting the words "ruminant animal's" before "stomach." That this is justified is borne out by the first sentence of the following quoted section, since the "bringing food from the stomach" mentioned there can only apply to ruminant animals. 
The memory is a storage organ, then, but similar in certain ways only to a ruminant animal's stomach: ${ }^{6}$

Perhaps, then, just as food is brought from the [animal's] stomach in the process of rumination, so also by recollection these things [past emotions] are brought up from the memory. But then [--and here Augustine returns to the idea of memory as the "stomach of the mind"--], why in the mind or "mouth" of the person speaking, that is to say reminiscing, about past gladness or sadness is there no taste [i.e., re-experience] of sweetness or bitterness? or is this a point where the incomplete resemblance between [human] thought and [animal] rumination makes the analogy misleading [my emphases]? ${ }^{7}$

"The incomplete resemblance between [human] thought and [animal] rumination" is already taken for granted here, in ways that are not often seen in medieval allusions to the memory stomach; it is evident that for Augustine, metaphor is not wholly trustworthy as a learning tool. (And when a metaphor is applied to the spiritual, it would seem doubly difficult to judge the appropriate limits of the metaphor.)

In his Sermon 149, Augustine moves to the spiritual level and interprets the symbolic implications of the cloven hoof and of rumination:

${ }^{6}$ Interestingly, the memory stomach seems to conflate two of Carruthers's memory paradigms, the storage room and digestion.

'Augustine, Confessions 10.14.22, p. 192. 
The cloven hoof is relevant to [human] conduct; [animal] rumination is in fact relevant to [human] wisdom. How is the cloven hoof relevant to conduct? Because a cloven hoof stumbles with difficulty; for stumbling signifies sin. But how is [animal] rumination relevant to the doctrine of wisdom? Because Scripture says: "A longed-for treasure reposes in the mouth of the wise man, but the foolish man gulps it down." ${ }^{8}$ Therefore he who hears, and through negligence becomes forgetful, as it were gulps down what he has heard; so that he no longer tastes in his mouth, destroying his hearing itself by his forgetfulness [i.e., destroying his ability to recognize God's word]. But he who meditates on the law of the Lord day and night, ${ }^{9}$ as if he is [an animal] ruminating, and in, so to speak, a kind of palate of the heart, is delighted by the taste of the word [my emphases]. ${ }^{10}$

This passage is written with a theological purpose, rather than the psychological purpose of the previous quotations; but here too Augustine seems repeatedly to

${ }^{8}$ Thesaurus desiderabilis requiescit in ore sapientis, vir autem stultus glutit illum. This is Augustine's version of Proverbs 21:20. It differs from the version in the Vulgate, which is: Thesaurus desiderabilis, et oleum in habitaculo iusti: Et imprudens homo dissipabit illud, "There is a treasure to be desired, and oil in the dwelling of the just: And the foolish man shall spend it."

${ }^{9}$ Here Augustine alludes to Joshua $1: 8$, the old Testament passage that makes earliest use of medita-. Augustine: "qui... in lege Domini meditatur die et nocte"; Joshua: "meditaberis in eo [the book of this law] diebus ac noctibus."

10 Augustine, Sermon 149.3, in Patrologiae cursus completus: series latina 38, ed. J.-P. Migne (Paris, 1841), 801. My translation. 
signal the metaphoric nature of the concepts under discussion: "as it were [quasi] gulps down what he has heard"; "as if [tanquam] he is ruminating, and, so to speak [quasi] in a kind of [quod(d)am] palate of the heart." I interpret these terms of qualification as "caution" signs, indicating that even as metaphors instruct, they may constrain.

Before discussing another important aspect of this text, I must turn to Augustinian uses of the spiritual nourishment metaphor that do not center on rumination. For these non-ruminative uses too can show Augustine's caution in applying the spiritual nourishment metaphor, even as he relishes the word-play the metaphor enables.

The passages I offer are from Augustine's Tractates on the Gospel of John. The Gospel of John itself makes strong and purposeful use of the spiritual nourishment metaphor, and Augustine delights in responding in kind. The first passages I quote carry no "caution" signs; they simply show Augustine's felicitous use of the spiritual nourishment metaphor, and his incorporation of apt scriptural verses that also make use of it. (The Eucharist, of course, is the spiritual nourishment that Augustine extols and expounds in his Tractates.) 
These men were far from the bread of heaven and they did not know how to hunger for it. They had weak jaws of the heart ${ }^{11}$. . . For indeed this bread searches out the hunger of the interior man; wherefore in another place he says, "Blessed are they who hunger and thirst for justice, for they shall have their fill."

Tractate 26.1 .1

To believe in [the Lord] is to eat the living bread. He who believes eats; he is nourished invisibly because he is reborn invisibly. He is an infant within; he is new within. Where he is renewed, there he is sated.

Tractate 26.1 .4

After the symbolic mystery of the miracle [the feeding of the five thousand] [Jesus] also delivers a discourse, that, if it is possible, they who have been fed may be fed, and that he may, with his discourses, fill the minds of those whose bellies he had filled with bread; but only if they grasp it.

Tractate $25 \cdot 10.1^{12}$

11 This phrase, "jaws of the heart," is an expression of the spiritual nourishment metaphor parallel to Plato's "eye of the soul," which concept is discussed in its relation to Augustine by Paul-Ludwig Landsberg, "Les sens spirituels chez Saint Augustin," in Dieu vivant no. 11 (1948): 83-105. A doctrine of the five spiritual senses seems to originate with origen (Karl Rahner, "Le début d'une doctrine des cinq sens spirituels chez Origène," in Revue d'ascétique et de mystique 13 [1932]: 113-45). I am researching the concept of the spiritual senses in relation to the spiritual nourishment metaphor.

12 Augustine, Tractates on the Gospel of John, 259, $260,246-47$. 
But in the following passages, Augustine again signals "metaphor," not directly, or with qualifying terms like "as if" (tanquam) but in a way that allows him to relish a colorful statement of the literal even as he rejects it:

"Jesus. . said to them, 'This is the work of God, that you believe in him whom he has sent.'" This, then, is to eat "not the food that perishes, but that which endures unto life everlasting." Why do you make ready your teeth and stomach? Believe, and you have eaten [my emphasis].

Tractate 25.12 .1

Similarly, interpreting John 6:50 ("This is the bread which cometh down from heaven; that if any man eat of it, he may not die") Augustine writes that this eating is

as pertains to the efficacy of the sacrament, not as pertains to the visible sacrament: he who eats within, not without; he who eats with his heart, not he who crushes with his teeth [my emphasis].

Tractate $26.12 \cdot 3^{13}$

"Why do you make ready your teeth and stomach?";

". . not he who crushes with his teeth"--here Augustine signals "metaphor" with bold erroneous literalisms that shock, even delight, the modern reader at least; they highlight the incongruity of taking the spiritual nourishment metaphor literally.

13 Ibid., 249, 270 . 
Henri de Lubac finds that the inadequacy of earthly language for the spiritual was widely recognized in patristic and medieval times. "One may note that the essence of this [view] comes from Saint Augustine, if, however, there is any reason to indicate a specific 'source' for such a common idea," he writes. ${ }^{14}$ de Lubac did not cite any Augustinian texts, however.

The caution over using the spiritual nourishment metaphor that I have found in Augustine seems compatible with the sense of Iinguistic inadequacy that Lubac writes of. On the other hand, Augustine observes in on Christian Doctrine that "things are perceived more readily through similitudes." In that work he expresses his satisfaction in constructing and hearing metaphors, offering his well-known observation that

in a strange way, I contemplate the saints more pleasantly when I envisage them as the teeth of the Church cutting off men from their errors and transferring them to her body after their hardness has been softened as if by being bitten and chewed. ${ }^{15}$

14 Henri de Lubac, Exégèse médiévale: Les quatre sens de l'Écriture vol. 2 pt. 2 (n.p.: Aubier, 1964), 152 .

15 Augustine, On Christian Doctrine (De doctrina Christiana) 2.6.7-8, trans. and with an introduction by D. W. Robertson, Jr., Library of Liberal Arts (Indianapolis: Bobbs-Merrill Educational Publishing, 
It could be relevant that in the Tractates on John Augustine is using the spiritual nourishment metaphor to try to express his perception of God's own attributes; similarly, in the passages on rumination quoted earlier, it is heavenly wisdom itself that the Christian will seek by the process deemed somewhat, but not entirely, like animal rumination. These cases contrast with that in which Augustine expresses satisfaction with the image of the saints as biting teeth: there he is alluding to human beings, not to God. And it is God for whom no words are adequate.

It must be the sacred and non-earthly character of God's own attributes, of heavenly wisdom, that explains why Augustine sometimes employs words or phrases that highlight the metaphorical nature, and thus the limitations, of the concept of spiritual nourishment. This explanation is supported by Augustine's attempt to make clear, in the Confessions, the inadequacy of another entity, light, as a metaphor for God. In a mystical experience, he tells us, he glimpsed

the immutable light higher than my mind--not the light of every day, obvious to anyone, nor a larger

1958), 37-38. In his introduction Robertson specifies that Augustine's expressed pleasure is an intellectual one $(X V)$. 
version of the same kind which would, as it were, have given out a much brighter light and filled everything with its magnitude. It was not that light, but a different thing, utterly different from all our kinds of light. It transcended my mind, not in the way that oil floats on water. . . It was superior because it made me, and I was inferior because I was made by it. ${ }^{16}$

Returning now to spiritual nourishment, we see that Augustine, with his frequent cautionary phrases about expressions of that metaphor, reminds himself and his readers of the incommensurability between the material and the spiritual--that is, of the inadequacy of metaphor for the spiritual. Yet still he must try to give voice to his glimpses of God, and so he embraces the spiritual nourishment metaphor with, we may say, cautious gusto.

\section{Dual-Sense Words and the Spiritual Nourishment Metaphor}

I noted earlier that Augustine's use of the spiritual nourishment metaphor gives us entrée to a characteristic of the Latin language that could have predisposed its users to the spiritual nourishment mindset. To facilitate a discussion of this idea, I will reproduce here the passage from Augustine's Sermon 149 discussed earlier:

The cloven hoof is relevant to [human] conduct; [animal] rumination is in fact relevant to [human]

16 Augustine, Confessions 7.10.16, p. 123. 
wisdom [sapientiam]. How is the cloven hoof relevant to conduct? Because a cloven hoof stumbles with difficulty; for stumbling signifies sin. But how is [animal] rumination relevant to the doctrine of wisdom [sapientiam]? Because Scripture says: "A longed-for treasure reposes in the mouth of the wise man [sapientis], but the foolish man gulps it down." Therefore he who hears, and through negligence becomes forgetful, as it were gulps down what he has heard; so that he no longer tastes [sapiat] in his mouth, destroying his hearing itself by his forgetfulness [i.e., destroying his ability to recognize God's word]. But he who meditates on the law of the Lord day and night, as if he is [an animal] ruminating, and in, so to speak, a kind of palate of the heart, is delighted by the taste [sapore] of the word.

In this passage Augustine has clustered--indeed, ingeniously linked--words whose roots carry both foodrelated and idea-related meanings. As he certainly intended, his calculated usage of words with doubled meanings has been noted before; ${ }^{17}$ my purpose here is to examine the implications of such word-play for the spiritual nourishment metaphor.

In the passage from Sermon 149, Augustine manipulates this doubling of meaning as follows. When he speaks of rumination's functions, i.e., not-forgetting (remembering) and pondering God's word, he links them to

${ }^{17}$ As, for example, by John W. Rettig, who mentions the frequent such use of sapio in the Tractates on the Gospel of John that he has translated, 236, n. 13. 
rumination's goal, true wisdom (sapientia). The word sapientia then leads him to the text from Proverbs that, in the version he used, discovers a treasure in the mouth of the wise man (sapientis). This felicitous juxtaposition, via the wise man, of wisdom and the mouth now enables Augustine to employ a series of Latin words that convey both intellectual and food-related meanings. Such dual-sense words are inherent vehicles for the metaphor Ideas are Food, and therefore for the spiritual nourishment metaphor.

Thus in this discussion of rumination--itself a dual-sense word from at least the third century B.C.E. ${ }^{18}$ --Augustine employs the following words built on sap-: Sap[iat] (sapio, verb): taste like; have discernment, be intelligent, understand. Sapient[is] (participle of sapio, adj. and noun): wise, wise man. Sapienti[am] (sapientia, noun): wisdom. Sapor[e] (sapor, noun): flavor, physical sense of taste; discernment in actions or speech. ${ }^{19}$ Note that two of the words built on the

18 see my page 23 .

19 For the meanings of these words I have consulted the Oxford Latin Dictionary, ed. P. G. W. Clare (New York: Oxford University Press, 1982), and Cassell's Latin Dictionary, revised J. R. V. Marchant and Joseph F. 
root sap- have but a single sense, while the other two carry both food- and idea-related senses. But the root with its two possibilities is present in all, and the two meanings reverberate throughout the passage.

Sap- is but one of a number of common Latin roots that convey both idea- and food-related meanings. This suggests that the metaphor Ideas are Food, which encompasses the spiritual nourishment metaphor, is inherent in the Latin language. Augustine's text illustrates how expression of the spiritual nourishment thought-pattern was facilitated by the dual-sense feature of the language of the church. ${ }^{20}$

From the early Middle Ages, monks daily read, ruminated, and copied Latin Christian texts, especially the vulgate and the patristic writers. Under the influence of those models, the commentators and preachers among them composed Latin texts of their own. The dual-

Charles (New York: Funk and Wagnalls, 1958 printing). I have not attempted to indicate every sense, or every shade of meaning, listed in the dictionaries.

20 Other examples of dual-sense words in Latin include concoquo (cook down, digest [food]; digest [a thought], ruminate [mentally], concoct [a plan]); and gusto (perceive with sense of taste; have knowledge or experience of). I am researching such Latin words and their implications for the spiritual nourishment metaphor. 
sense vocabulary of the language they were using would have continuously reinforced the spiritual nourishment mind-set within Western monasticism. 
CHAPTER 4

\section{WHY MIGHT FOOD SYMBOLIZE THE SPIRITUAL?}

Why was food chosen, and reiterated over so many centuries, as a material symbol for the spiritual in Judaeo-Christian culture? Feeley-Harnik raises a similar question, without settling on answers, at the conclusion of The Lord's Table: "Why was food the language," she asks, in which the Jews expressed their relationships with humans and with God? ${ }^{1}$

Consider the spiritual nourishment metaphor. The human activity of rumination, which was carried out by repeatedly mouthing words, was named for its visual resemblance to animal rumination. But visual resemblance cannot explain the use of food as symbol in most expressions of the spiritual nourishment metaphor. These considerations imply that the spiritual nourishment mindset or metaphor must represent a convergence of expressions from varied origins. A number of factors, then, could have influenced the choice, and/or the

1 Feeley-Harnik, The Lord's Table, 166. 
maintenance, of food as a metaphor for the spiritual. I will consider here the influence of human physiology on the symbolic use of food.

Hunger and thirst are the basic motivators of animal activity. This should alert us to a biological level of explanation for the use of food as a metaphor for the spiritual. Such an explanation suggests that food, because it is essential for physical life, is an apt metaphor for what a culture holds spiritually essential.

\section{Food as Symbol in the Hebrew Culture}

Without alluding to its roots in physiology, several authors, including Feeley-Harnik, have seen that symbolic use of food can be expected in a society where access to it is uncertain. ${ }^{2}$ In the early Hebrew culture in which the spiritual nourishment metaphor developed, the preoccupation with assuring adequate food on a daily basis must have been intense. An intimation of such preoccupation was glimpsed by two twentieth-century writers who researched varieties of flatbreads across

2 Ibid., 167-68; Caroline Walker Bynum, Holy Feast and Holy Fast: The Religious Significance of Food to Medieval Women (Berkeley, Los Angeles, London: University of California Press, 1987), 1-2; Bynum cites also Peter Brown. 
Islamic cultures of the Middle East, North Africa, and Asia; they came to comprehend "the unique relationship. - to the food they eat" of those who rely on flatbreads. Unlike urban North Americans, they found, "in flatbread cultures most people have a very clear idea of where the food they eat each day comes from, of how it is grown or raised, how it is prepared and cooked." ${ }^{3}$ Such detailed practical knowledge would have been the norm in the Bible lands of the ancient Levant, a region of irregular rainfall where food production depended on rigorous water management. Under such water management, much of its terrain could be made to produce food surpluses, but drought or other disruptions of water supplies often led to famine. ${ }^{4}$

The writer of the book of Job reveals how precious food was to the Hebrews. When Eliphaz, the first of Job's comforters, extols God to Job, rainfall is the first of God's gifts that he names:

Wherefore I will pray to the Lord, . .

3 Jeffrey Alford and Naomi Duguid, "On the Flatbread Trail," Aramco World 46, no. 5, September-October 1995, 24.

${ }^{4}$ W. M. S. Russell, Man, Nature and History (London: Aldus, 1967; Garden City: Natural History Press for the American Museum of Natural History, 1969), chaps. 5, 7, esp. pp. 91-92, 133-36. Feeley-Harnik too mentions famine and drought (167-68). 
Who doth great things . - without number:

Who giveth rain upon the face of the earth, and watereth all things with waters.

Twice later in the same exhortation, Eliphaz avers that those who accept God's correction will ultimately be spared during famine. ${ }^{5}$

The word famine occurs ninety-one times in the old Testament. ${ }^{6}$ Thus not only did famine figure repeatedly in Hebrew history, it would have been brought to renewed consciousness each time the ancient texts were read and meditated.

From physiological considerations, then, we can see how food could have become the metaphorical name, in the Hebrew culture, for what sustains spiritual life.

\section{Food as Symbol in the Cistercian Culture}

Twelfth-century Cistercian culture offers another perspective from which to evaluate the relationship between food dearth and food symbolism suggested by the Hebrew culture. In the Cistercian order, as in other reforming orders of the period, eating was willingly curtailed: the Cistercians, formed partly in response to

5 Job $5: 8-10,20,22$.

E The New Strong's Exhaustive Concordance of the Bible, by James Strong (Thomas Nelson, 1990). 
ascetic laxity in the established Benedictine monasteries, sought to return to strict observance of the rule of st. Benedict, and even surpassed the rule in rigor. Cistercians' Lenten fasts, for example, were more spartan than those ordained by the rule. Bernard of Clairvaux, head of the order and the most influential spiritual leader of the twelfth century, in Bynum's words "practiced severe abstinence" beyond the regime followed by his monks.

Bernard, as we know, wrote prolifically, for his monks and for a wide general audience. ${ }^{8}$ What role do food images take in his writings? It will probably not surprise to learn that, in Dutton's words, "eating and drinking appear throughout [Bernard's] sermons and spiritual treatises as the central metaphor for coming to the understanding of God."s

7 This paragraph draws on $\mathrm{R}$. W. Southern, Western Society and the Church in the Middle Ages (Harmondsworth: Penguin, 1970), 251; Bynum, Holy Feast and Holy Fast, 4243; and Russell, Man, Nature and History, 140.

8 For Bernard's audiences, see Jean Leclercq, introduction to on the song of Songs vol. 2, by Bernard of Clairvaux, trans. Kilian Walsh (Kalamazoo: Cistercian Publications, 1976), vii-xxx (esp. xxiii-xxx).

9 Marsha L. Dutton, "Eat, Drink, and Be Merry: The Eucharistic Spirituality of the Cistercian Fathers," in Erudition at God's Service, ed. John R. Sommerfeldt (Kalamazoo: Cistercian Publications, 1987), 6. 
How deeply the spiritual nourishment mind-set was engrained in Bernard is suggested by the following: in the first, introductory, sermon of his eighty-six on the Song of Songs, a scriptural text built on sexual metaphor, Bernard actually opens with an outpouring of the spiritual nourishment metaphor:

The preacher who desires to follow st Paul's method of teaching will give [people in the world] milk to drink rather than solid food, and will serve a more nourishing diet to those who are spiritually enlightened: . . Be ready then to feed on bread rather than milk. Solomon has bread to give that is splendid and delicious, the bread of that book called the song of Songs. Let us bring it forth then if you please, and break it. . .

[Ecclesiastes and Proverbs] are two loaves of which it has been your pleasure to taste, loaves you have welcomed as coming from the cupboard of a friend. Now approach for this third loaf that, if possible, you may always recognize what is best. . .

\section{- . But who is going to divide this loaf?}

The Master of the house is present, it is the Lord you must see in the breaking of the bread. . . . I myself am one of the seekers, one who begs along with you for the food of my soul, the nourishment of my spirit. . . " "Little children go begging for bread; no one spares a scrap for them;" they await it from your merciful love. O God most kind, break your bread for this hungering flock, through my hands indeed if it should please you. ${ }^{10}$

10 Bernard of Clairvaux, On the Song of Songs Sermon 1.1-2, in on the song of Songs vol. 1, trans. Kilian Walsh, with an introduction by M. Corneille Halflants (Kalamazoo: Cistercian Publications, 1981), pp. $1-3$. 
That the ascetic Bernard chose repeated expressions of the spiritual nourishment metaphor to introduce this major work, on a scriptural text built on sexual metaphor, again suggests a relationship between food dearth and choice of food as metaphor.

Bernard's use of certain other images can help us explore a psychological aspect of the relationship between food dearth and food metaphor. That relationship seems parallel to a relationship that Bernard apparently made use of when he used metaphors of aggression and sexuality. Leclercq finds that when Bernard addressed works to his own monks only, as he did with his Parables and Sentences, he employed a striking number of military and sexual images. Leclercq explains Bernard's use of this imagery as follows:

Many of Bernard's monks were former knights, participants in the chivalric culture, who now as monks had voluntarily renounced earthly aggression and sexuality. In the Parables and the Sentences, Bernard interwove his own references to aggression and sexuality with biblical texts that used similar language metaphorically. By this attempt to associate the old words and experiences with new meanings, Bernard 
acknowledged and made use of, rather than avoided, his monks' former experiences and probable present impulses. His strategy, Leclercq believes, was: "Much better to face these basic human impulses at the conscious, voluntary level in order to control them, than to strive to continuously repress them." 11

Bernard's apparent strategy in using these non-food images leads me to consider a possible psychological parallel with the use of food metaphors. In societies where food access is frequently restricted, food images could help to compensate for the restriction of actual food: the spiritual nourishment metaphor could move hearers to embrace the symbolized entity, spiritual nourishment, as a replacement for material nourishment in short supply.

Bernard's use of imagery, in sum, supports the idea suggested by the use of food imagery among the ancient Hebrews: that the choice of an earthly vocabulary for

11 This account has been based on Leclercq, Monks and Love, chap. 5 passim. Quotation p. 97. (Leclercq seems to be suggesting that Bernard has attempted a Pavlovian solution to a Freudian problem.) Leclercq finds Bernard's use of sexual and military images in the Parables and the sentences "incomparably greater" than in the writings of Anselm of Bec for his monks, most of whom had lived in the monastery since childhood (Monks and Love, 104). 
spiritual desiderata can be influenced by dearth, or the prospect of dearth, of the earthly entity used as a symbol. 
CHAPTER 5

\section{CONCLUSION}

Christianity is pervaded by a large array of images in which the spiritual realities are symbolized as food. In this thesis I have shown that these images are manifested in three media, words, action, and visual representation. My consideration of a number of such images from a wide period, ranging from the early old Testament to the present, demonstrates their relatedness as expressions of an overarching spiritual nourishment metaphor. This thesis begins to trace the history of the metaphor in Christianity.

My study leads to these conclusions about the metaphor:

Existence and scope. An overarching spiritual nourishment metaphor, expressed in verbal, visual, and enacted forms, is a demonstrable characteristic of Christian spirituality over two millennia.

Meaning. Members of the ancient Hebrew and the medieval Cistercian cultures routinely used the spiritual 
nourishment metaphor; in each of these cultures, for different reasons, dearth of food was never far from people's consciousness. Their uses of the metaphor support the conclusion that when a substance necessary for human survival is in short supply, its use as a symbol communicates that what is symbolized, here the spiritual realities, is highly important to the culture. In the Hebrew and the medieval Cistercian cultures, the spiritual nourishment metaphor expresses the depth of the people's dependence on God. This interpretation is supported by a text from Aelfric, the Anglo-Saxon abbot of Eynsham (d. ca. 1010): "Christ is called 'bread'," wrote Aelfric, "because he is our life, and the angels'." This statement implies that bread is central to earthly life, and that what is central to the spiritual life may equally be called bread. ${ }^{1}$

Within this basic meaning for the spiritual nourishment metaphor, there is a further implication: just as material food enables physical growth, spiritual nourishment will enable spiritual maturity. This meaning is observable in the function of monastic rumination,

1 Aelfric, "Sermon on the Sacrifice on Easter Day" (Catholic Homily II 15), in Anglo-Saxon Prose, ed. and transl. Michael Swanton (London: J. M. Dent and Sons; Totowa, N.J.: Rowman and Littlefield, 1975), 91. 
that function being to facilitate union with God. It is expressed in the Scriptures: "As newborn babes," Peter urges, "desire the rational milk without guile, that thereby you may grow into salvation" ( 1 Peter $2: 2$ ). ${ }^{2}$ Indeed, we find Paul noting that in one case the desired spiritual growth has not yet occurred:

"And I, brethren, could not speak to you as unto spiritual, but as unto carnal. As unto little ones in christ. I gave you milk to drink, not meat: for you were not able as yet. But neither indeed are you now able; for you are yet carnal."

1 Cor. $3: 1-2$

(Note Paul's metaphorical distinction between levels of nourishment and therefore of spiritual wisdom.)

Multiple origins. Expressions of the spiritual nourishment metaphor are immensely varied. Their variety is illustrated by such exemplars as the action of rumination, which was named for its visual resemblance to the animal activity, and the Eucharist, which can be partially described as a substance (Christ's flesh) that appears to be a different kind of substance (bread), and which against expectation assimilates the consumer to itself instead of the reverse. ${ }^{3}$. Such variety strongly

2 ". . ut in eo crescatis in salutem."

3 For a statement of the point that christ in the Eucharist assimilates the consumer to himself, see Alessandro Diotallevi, La beneficenza di Dio. . . 
suggests that the metaphor represents a convergence of expressions from varied origins. Further exploration of the history of the metaphor should focus on this point. Continuity. The continuity of the spiritual nourishment metaphor over several millennia is shown by the time span, from the old Testament to the twentieth century, over which instances of it have been actively used in religious practice. Numerous potential exemplars of the metaphor over these centuries remain to be investigated. As I have indicated, I am investigating, as expressions of the metaphor, the phenomena of fasting, reading in the monastery refectory, the sculptured Romanesque capital at Vézelay known as the Mystic Mill, and the feeding aspect of the verbal metaphor Jesus as Mother. I am also investigating, in relation to the metaphor, the concept of the spiritual senses, and the dual-sense feature of Latin.

Central importance in Christianity. I conclude that the spiritual nourishment metaphor is an integral and central element of Christian spirituality. Indeed, the

considerazioni (Venice: A. Poletti, 1716), 253, 258; quoted in Piero Camporesi, "The Consecrated Host: A Wondrous Excess," trans. Anna Cancogne, in Fragments for a History of the Human Body, pt. 1, ed. Michel Feher (New York: Zone, 1989), 227. 
centrality of the Last Supper and the Eucharist to Christianity means that it cannot be otherwise, for the Eucharist is the supreme exemplar of the spiritual nourishment metaphor, with both enacted and verbal components. ${ }^{4}$ The actions and words of Christ instituted the Eucharist; in each reenactment, the priest acts and speaks to bring about the change from bread and wine to Christ's substance, and God "acts" to become physically present. The Eucharist differs from all other exemplars of the spiritual nourishment metaphor, however, in that symbol and symbolized are one. ${ }^{5}$

Alongside the Eucharist, other expressions reinforce the spiritual nourishment metaphor in Christian practice. These expressions are important routes for approaching God and the spiritual. The metaphor came to Christianity

4 Bynum, in Holy Feast and Holy Fast, writes that "although Christians evolved a fixed liturgy for their holy meal only very slowly, the eucharist (sic) was by 200 the central act of the church" (48, no source given). For a presentation of theological views on ways in which the Lord was thought to be present in the Eucharist at various early periods in Christianity, see Gary Macy, The Theologies of the Eucharist in the Early Scholastic Period (Oxford: Clarendon Press, 1984), 18-21.

5 of this identity between symbol and symbolized in the Eucharist, John W. Rettig writes: "A sacrament is a sign that can both signify a reality and be the reality at the same time" (Rettig in Augustine, Tractates on the Gospel of John, trans. John Rettig, 268 n. 34). 
from the Hebrew tradition, as its verbal uses in the old Testament reveal. It became a basic element of spiritual expression in the New Testament; the Gospel of John provides in Chapter 6 two sustained examples, the texts on the bread of life and the feeding of the five thousand. The enacted metaphor rumination also came to Christianity from the Hebrew tradition; Christian rumination incorporates a strand from the classical tradition as well. ${ }^{6}$ The Jewish writer Aristeas saw in animal rumination an evocation of meditation on God's works. The early Christian writer of the Epistle of Barnabas found rumination as important to Christianity as keeping the Commandments; this would have been so because it enabled access to the meaning of the scriptures, the central texts of the faith. Its focus on the Scriptures additionally made rumination a force for community cohesion around the ideals that drew Christians together. Finally, in Christian monasticism, rumination became an important method for approaching the central monastic goal, union with God.

- See my p. 23; see also Jean Leclercq, "Ways of Prayer and Contemplation II. Western," trans. Dennis Tamburello, in Christian Spirituality: Origins to the Twelfth Century, ed. Bernard McGinn and John Meyendorff, with Jean Leclercq (New York: Crossroad, 1985), 418. 
Augustine's writings demonstrate another aspect of the integral relationship of the spiritual nourishment metaphor to Christian culture. His texts on spiritual nourishment sometimes play on words whose roots convey both food-related and idea-related meanings. From these usages we grasp that the spiritual nourishment metaphor would have been reinforced in the western church by the dual-sense vocabulary of Iatin, the language of the Vulgate and of the patristic texts, both of which were used by monks as inspiration and models for their own Latin commentaries.

Augustine's writings demonstrate as well his understanding that the spiritual nourishment metaphor has limitations: he explicitly distinguishes between memory and its metaphor the memory stomach, and he warns against understanding too literally the Eucharistic metaphor. His cautions implicitly suggest the question, why then use the spiritual nourishment metaphor--or, even, metaphor itself? Which question leads us to another, What is the function of the spiritual nourishment metaphor?

A clue to Augustine's understanding of its function lies in the fact that, despite his sense of its limitations, he persists in using it: he must use it, I 
believe, because it is the only means he knows to express what he "senses" or has experienced about God. Which apparent instinct accords with the judgment of Lakoff and Johnson 1500 years later on the function of metaphor, that it "is one of our most important tools for trying to comprehend partially what cannot be comprehended totally: our feelings, aesthetic experiences, moral practices, and spiritual awareness."

Lakoff and Johnson, Metaphors We Live By, 193. 


\section{WORKS CONSULTED}

Adnès, Pierre. "Goût spirituel." In Dictionnaire de spiritualité ascétique et mystique doctrine et histoire t. 6, 626-44. Paris: Beauchesne, 1967.

Aelfric. "Sermon on the Sacrifice on Easter Day" (Catholic Homily II 15). In Anglo-Saxon Prose, ed. and transl. Michael Swanton, 88-97. London: J. M. Dent and Sons, 1975; Totowa, N. J.: Rowman and Littlefield, 1975.

Alford, Jeffrey and Naomi Duguid. "On the Flatbread Trail." Aramco World 46, no. 5 (September/October $1995), 16-25$.

Aristeas to Philocrates (Letter of Aristeas). Edited and translated by Moses Hadas. New York: Harper and Brothers, for the Dropsie College for Hebrew and Cognate Learning, 1951.

Augustine. Confessions. Translated and with an introduction and notes by Henry Chadwick. Oxford and New York: Oxford University Press, 1991. On Christian Doctrine (De doctrina Christiana). Translated and with an introduction by D. W. Robertson, Jr. The Library of Liberal Arts. Indianapolis: Bobbs-Merrill, 1958.

- Sermon 149. In Patrologiae cursus completus: series latina, ed. J.-P. Migne, 38: 800-807. Paris, 1841 .

Tractates on the Gospel of John 11-27 (In Iohannis Evangelium tractatus). Translated by John W. Rettig. Fathers of the Church: A New Translation, vol. 79. Washington: Catholic University of America Press, 1988.

Beardsley, Monroe G. "Metaphor." In Encyclopedia of Philosophy 5: 284-89. New York: Macmillan and The Free Press, 1967; London: Collier Macmillan, 1967. Reprinted 1972 . 
Beckwith, John. Early Christian and Byzantine Art. 2d (integrated) ed. Harmondsworth: Penguin, 1979.

Bernard of Clairvaux. On the song of Songs Sermon 1 . In On the Song of Songs vol. 1, trans. Kilian Walsh, with an introduction by M. Corneille Halflants, 1-7. Kalamazoo: Cistercian Publications, 1981.

- On the song of songs sermon 33. In on the Song of Songs vol. 2, trans. Kilian Walsh, with an introduction by Jean Leclercq, 144-59. Kalamazoo: Cistercian Publications, 1976; London and Oxford: Mowbray, 1976.

Bynum, Caroline Walker. Holy Feast and Holy Fast: The Religious Significance of Food to Medieval Women. Berkeley, Los Angeles, and London: University of California Press, 1987.

- Jesus as Mother: Studies in the Spirituality of the High Middle Ages. Berkeley, Los Angeles, and London: University of California Press, 1982.

Camporesi, Piero. "The Consecrated Host: A Wondrous Excess." Translated by Anna Cancogne. In Fragments for a History of the Human Body, pt. 1, ed. Michel Feher, 221-37. New York: Zone, 1989.

Carruthers, Mary. The Book of Memory: A Study of Memory in Medieval Culture. Cambridge: Cambridge University Press, 1990.

Cassell's Latin Dictionary. Revised by J. R. V. Marchant and Joseph F. Charles. New York: Funk and Wagnalls, 1958 printing.

Chenu, Marie-Dominique. "La décadence de l'allégorisation." In L'homme devant Dieu: Mélanges offerts au Père Henri de Lubac. Vol. 2. Paris: Aubier, 1964.

Curtius, Ernst Robert. European Literature and the Latin Middle Ages. Bollingen Series no. 36. Translated by Willard R. Trask. New York: Pantheon, 1953.

de Lubac, Henri. Exégèse médiévale: Les quatre sens de I'Écriture. T. 2, pt. 2. N.p.: Aubier, 1964.

de Voguie, Adalbert. The Rule of Saint Benedict: $A$ Doctrinal and Spiritual Commentary. Translated by John Baptist Hasbrouck. Kalamazoo: Cistercian Publications, 1983. 
- To Love Fasting: The Monastic Experience. Translated by Jean Baptist Hasbrouck. Petersham, Mass.: Saint Bede's Publications, 1989.

Dutton, Marsha L. "Eat, Drink, and Be Merry: The Eucharistic Spirituality of the Cistercian Fathers." In Erudition at God's Service, ed. John R. Sommerfeldt, 1-31. Kalamazoo: Cistercian Publications, 1987.

Épitre de Barnabé (Epistle of Barnabas). Translated, introduced, and with notes by Pierre Prigent. Greek text established by Robert A. Kraft. Sources Chrétiennes, no. 172. Paris: Editions du Cerf, 1971.

Feeley-Harnik, Gillian. The Lord's Table: The Meaning of Food in Early Judaism and Christianity. Washington and London: Smithsonian Institution Press, 1994. (Reprint, with additions, of The Lord's Table: Eucharist and Passover in Early Christianity. Publisher not given, 1981.)

Firth, Raymond. Symbols Public and Private. Symbol, Myth and Ritual Series, ed. Victor Turner. Ithaca: Cornell University Press, 1973.

Herbert, Rembert. "The Way of Angels." In Parabola 14, no. 2 (Summer [May] 1989): 77-86.

Ignatius of Antioch. Letter to the Trallians. Translated by William R. Schoedel. In Ignatius of Antioch: A Commentary on the Letters of Ignatius of Antioch, by William R. Schoedel, ed. Helmut Koester, 135-62. Philadelphia: Fortress, 1985.

Jeanneret, Michel. A Feast of Words: Banquets and Table Talk in the Renaissance. Translated by Jeremy Whiteley and Emma Hughes. Chicago: University of Chicago Press, 1991.

Jungmann, Joseph A. The Mass of the Roman Rite: Its Origins and Development (Missarum Sollemnia). Translated by Francis A. Brunner. 2 vols. N.p.: Benziger Brothers, 1951 and 1955. Replica edition, Westminster, Md.: Christian Classics, 1986; reprinted 1992 .

Lakoff, George and Mark Johnson. Metaphors We Live By. Chicago and London: University of Chicago Press, 1980 . 
Landsberg, Paul-Ludwig. "Les sens spirituels chez Saint Augustin." Dieu vivant no. 11 (1948): 83-105.

Leclercq, Jean. The Love of Learning and the Desire for God: A study of Monastic Culture, 3d ed. Translated by Catharine Misrahi. New York: Fordham University Press, 1982.

"Monasticism and Asceticism II. Western Christianity." Translated by Dennis Tamburello. In Christian Spirituality: Origins to the Twelfth century, ed. Bernard McGinn and John Meyendorff, with Jean Leclercq, 113-31. World Spirituality: An Encyclopedic History of the Religious Quest, vol. 16. New York: Crossroad, 1985.

- Monks and Love in Twelfth-Century France: Psycho-Historical Essays. Oxford: Clarendon Press, 1979 .

- La spiritualité de Pierre de Celle. Librairie philosophique. Paris: J. Vrin, 1946.

- "Ways of Prayer and Contemplation II.

Western." Translated by Dennis Tamburello. In

Christian Spirituality: Origins to the Twelfth

Century, ed. Bernard McGinn and John Meyendorff, with Jean Leclercq, 415-26. World Spirituality: An Encyclopedic History of the Religious Quest, vol. 16. New York: Crossroad, 1985.

Macy, Gary. The Theologies of the Eucharist in the Early Scholastic Period. Oxford: Clarendon Press, 1984.

McEague, Sallie. "Metaphor, Parable, and Scripture." In Metaphorical Theology: Models of God in Religious Language, 31-66. Philadelphia: Fortress, 1982.

Mosedale, Susan. Review of Bread, Wine, and Money: The Windows of the Trades at Chartres Cathedral, by Jane Welch Williams. The Historian 56, no. 3 (Spring 1994): 618-19.

Murphy, James J. Rhetoric in the Middle Ages: A History of Rhetorical Theory from Saint Augustine to the Renaissance. Berkeley, Los Angeles, and London: University of California Press, 1974.

Oxford Latin Dictionary. Edited by P. G. W. Clare. New York: Oxford University Press, 1982. 
Petrus Cellensis (Peter of Celle). Commentaria in Ruth; Tractatus de tabernaculo. Edited by G. de Martel. Corpus Christianorum, continuatio mediaeualis 54. Turnhout: Brepols, 1983.

- Liber de panibus (Book of Breads). In

Patrologiae cursus completus: series latina, ed. J.P. Migne, 202: 927-1046. Paris, 1855.

Rahner, Karl. "Le début d'une doctrine des cinq sens spirituels chez origène." Revue d'ascétique et de mystique 13 (1932): 113-45.

Rousse, Jacques. "Lectio divine et lecture spirituelle" I. In Dictionnaire de spiritualité ascétique et mystique doctrine et histoire, t. 9, 470-87. Paris: Beauchesne, 1976.

Rudolph, Conrad. Artistic Change at St-Denis: Abbot Suger's Program and the Early Twelfth-Century Controversy over Art. Princeton: Princeton University Press, 1990.

Ruppert, Fidelis. "Meditatio-Ruminatio: Une méthode traditionelle de méditation." Collectanea Cisterciensia 39 (1977): 81-93.

Russell, W. M. S. Man, Nature and History: Controlling the Environment. London: Aldus, 1967; Garden City: Natural History Press, for the American Museum of Natural History, 1969.

Serlo of Wilton. Commentary on the Pater Noster in MS. Trinity College 19. Translated by Lawrence C. Braceland. In Braceland, "Thomas Becket and Monks' Bread," in Benedictus: Studies in Honor of $S t$ Benedict of Nursia, ed. E. Rozanne Elder, 108-14. Kalamazoo: Cistercian Publications, 1981.

Southern, R. W. Western Society and the Church in the Middle Ages. Harmondsworth: Penguin, 1970.

TeSelle, Sallie McFague. "Metaphor: The Heart of the Matter." In Speaking in Parables: A Study in Metaphor and Theology, 43-65. Philadelphia: Fortress, 1975.

von Severus, Emmanuel and Aimé Solignac. "Méditation" I. In Dictionnaire de spiritualité ascétique et mystique doctrine et histoire, $t$. 10, 906-914. Paris: Beauchesne, 1980. 
West, Philip J. "Rumination in Bede's Account of Caedmon." Monastic Studies 12 (1976): 217-26.

Westen, Drew. Psychology: Mind, Brain, and Culture. New York: Wiley, 1996.

Williams, Jane Welch. Bread, Wine, and Money: The Windows of the Trades at Chartres Cathedral. Chicago and London: University of Chicago Press, 1993.

Zizioulas, John D. "The Early Christian Community." In Christian Spirituality: Origins to the Twelfth Century, ed. Bernard McGinn and John Meyendorff, with Jean Leclercq, 23-43. World Spirituality: An Encyclopedic History of the Religious Quest, vol. 16. New York: Crossroad, 1985. 